\title{
THERMAL PROPERTIES OF A MIXTURE OF SYNTHETIC AND NATURAL ESTERS IN TERMS OF THEIR APPLICATION IN HIGH VOLTAGE POWER TRANSFORMERS
}

\section{WŁAŚCIWOŚCI CIEPLNE MIESZANINY ESTRÓW SYNTETYCZNYCH I ESTRÓW NATURALNYCH W ASPEKCIE ZASTOSOWANIA W TRANSFORMATORACH DUŻEJ MOCY*}

\begin{abstract}
The article presents research results of thermal properties of mixtures of synthetic and natural esters in terms of their application in the cooling system of a high-voltage power transformer during its operation. The investigated properties of an analysed mixture were: thermal conductivity coefficient $\lambda$, kinematic viscosity $v$, density $\rho$, specific heat $c_{p}$, and thermal expansion $\beta$. On the basis of presented research results, the authors determined the heat transfer factor $\alpha$ of a mixture of synthetic and natural esters. This factor defines the ability of an insulating liquid to transport heat in the transformer, thus determining its reliability. For the research the authors used the following percentage proportions of the mixture of both the esters: 100/0, 95/5, 80/20, 50/50, 20/80, 5/95, 0/100. The measurements were taken for the temperatures: $25^{\circ} \mathrm{C}, 40^{\circ} \mathrm{C}, 60^{\circ} \mathrm{C}$, and $80^{\circ} \mathrm{C}$.
\end{abstract}

Keywords: power transformers, natural esters, synthetic esters, heat transfer factor.

\begin{abstract}
W artykule przedstawiono wyniki badań właściwości cieplnych mieszaniny estrów syntetycznych i estrów naturalnych, w aspekcie ich zastosowania w układzie chłodzenia transformatora wysokiego napięcia w trakcie jego eksploatacji. Badanymi właściwościami analizowanej mieszaniny były przewodność cieplna właściwa $\lambda$, lepkość kinematyczna v, gestość $\rho$, ciepło właściwe $c_{p}$ oraz rozszerzalność cieplna $\beta$. W oparciu o przedstawione wyniki badań określono współczynnik przejmowania ciepła $\alpha$ mieszaniny estrów syntetycznych i estrów naturalnych. Wspótczynnik ten określa zdolność cieczy elektroizolacyjnej do transportu ciepla w transformatorze, warunkujac tym samym jego niezawodność. Do badań wykorzystano następujace procentowe proporcje mieszaniny obu estrów: $100 / 0,95 / 5,80 / 20,50 / 50.20 / 80,5 / 95,0 / 100$. Pomiary przeprowadzono dla temperatury: $25^{\circ} \mathrm{C}, 40^{\circ} \mathrm{C}, 60^{\circ} \mathrm{C} i 80^{\circ} \mathrm{C}$.
\end{abstract}

Stowa kluczowe: transformatory energetyczne, estry naturalne, estry syntetyczne, wspótczynnik przejmowania ciepta.

\section{Introduction}

The power transformer is one of the most important electric power devices. Its key element is the insulating system; transformer reliability and its long operation depends on it. A substantial majority of used transformers is filled with insulating liquids. Due to their good dielectric properties, these liquids function as electric insulation. Moreover, they also have advantageous thermal properties (thermal conductivity, viscosity, specific heat, density, and thermal expansion), so that they also play the role of a cooling agent $[13,26]$. Taking into consideration the fact that heat transfer proceeds along the following way: heat source $\rightarrow$ paper impregnated with liquid $\rightarrow$ insulating liquid $\rightarrow \operatorname{tank} \rightarrow$ air, thermal properties of the liquid filling the inside of the transformer are of high importance in the process of this transfer $[4,14-16]$

The most frequently used insulating liquid in the transformer, because of a low price and very well investigated properties, is mineral oil $[10,20,26,32]$. However, more and more restrictive regulations and requirements concerning reliability of electric power devices filled with liquids influence reduction of its domination $[2,6,7,17$, $18,23]$. Therefore, research centres all over the world conduct numerous investigations on liquids alternative to mineral oil. These include mainly synthetic esters and natural esters [3, 4, 12, 21]. These liquids are characteristic of many properties, which in reference to mineral oil, are considered as their advantages. They are, first of all, ecological values such as biodegradability and non-toxicity, and also operation safety connected with their high flash point and fire point $[12,21]$.

Lately, the process of replacing the insulating liquid filling the transformer with another (retrofilling) has been more and more popular. This happens when the transformer up to now has been filled with one liquid (usually mineral oil) and now it is filled during a repair with another liquid (most often with synthetic or natural esters) [8, 18]. Retrofilling does not guarantee full removing of the original liquid because its small amount remains in the saturated paper insulation, windings, core, and other hardly-accessible crevices of the transformer. Then, unintentionally, a mixture is created which consists of remains of the original liquid (its amount does not exceed 8\%) and the new liquid that the modernized unit is filled with, as described by Fofana et al in [8]. There are also investigations concerning intentional use of two or more insulating liquids in order to obtain a mixture characteristic of better properties in reference to the base liquids. This research concerns most often mixtures of mineral oil with synthetic or natural esters $[6,7,10,11,17,22,23,27,30]$.

The research on the mixtures which are currently conducted in many research centres all over the world, concern mainly their electric properties, not thermal ones, which is not a proper approach. We

(*) Tekst artykułu w polskiej wersji językowej dostępny w elektronicznym wydaniu kwartalnika na stronie www.ein.org.pl 
should take into consideration that the application of insulating liquid mixtures, which in reference to the base liquids are characteristic of better electric properties and worse thermal properties, will result in accelerating the ageing process of the transformer's insulating liquid as a consequence of higher work temperature. As a result, this will reduce the time of its operation. Therefore, the research on the mixtures should tend to combine their electric, physicochemical, and thermal properties as described Nadolny et al in [19]. Dua et al undertook such an attempt in [5], in which they analysed a possibility to apply mixtures of insulating liquids while paying attention to their most important properties. However, with a lack of full information concerning thermal properties of the mixtures, such an approach can be difficult or impossible to do.

As it was mentioned before, a considerable number of articles referring to mixtures of insulating liquids present research results of their electric properties. In $[6,27,29,30]$ the authors present research results concerning the influence of proportions of oil and esters and the level of ageing on such electric properties as the dielectric loss factor $\operatorname{tg}(\delta)$, electric permeability, and breakdown voltage. In turn, Suwarno in [28] presented the influence of thermal ageing of a mixture of mineral oil and natural ester on such electric properties as breakdown voltage, resistivity, the dielectric loss factor, and electric permittivity. Moreover, Trnka et al in [31] show research results concerning biodegradability of mixtures of mineral oil and natural ester. McShane et al in [18] also present information concerning the influence of proportions of mineral oil and natural ester on the flash point and fire point as well as pour point.

The literature does not provide complete information concerning thermal properties of insulating liquid mixtures. The only available data are those concerning selected thermal properties of mixtures of mineral oil with synthetic esters and mixtures of mineral oil with natural esters. In $[23,30]$ we can find information concerning viscosity of a mixture of mineral oil and synthetic esters depending on their proportions. The authors also provide information concerning the influence of temperature on mixture viscosity whose mineral oil content is $20 \%$ and $80 \%$. In turn, McShane et al in [18] present information concerning viscosity of a mixture of mineral oil and natural esters depending on their proportions. However, these data were presented only for the mixtures whose temperatures were $40^{\circ} \mathrm{C}$ and $100^{\circ} \mathrm{C}$. In $[27,29]$ we can find data concerning the influence of temperature and the proportions on the density of mixtures based on mineral oil and natural esters.

There is no investigations according thermal properties of insulating liquids mixtures. As it can be seen on the basis of references, only partial information about viscosity and density of mineral oil and the esters are available. There is no information according the influence of temperature and mixture proportion on rest thermal properties, such as thermal conductivity, specific heat and thermal expansion. There is no information about mixtures of natural esters and synthetic esters, either.

Independently of the way the mixture is created, the purpose of its application is the improvement of insulating liquid properties. Thus the research on properties of mixtures of different insulating liquids are primary in terms of their influence on the period of the transformer's life and adapting it to existing standards and regulations. Moreover, another important issue is compatibility of the newly created mixture with the remaining materials which make the insulating system of the transformer, because only such a mixture will enable prolonging its operation period and reliable work. Therefore, complete information about thermal properties of insulating liquid mixtures are desirable and they will also allow completing missing knowledge in the field of properties of new insulating liquids, which is the focus of this article.

\section{Research goal and range}

The goal of the undertaken investigations was to determine the influence of proportions of synthetic esters with natural esters on thermal properties of the created mixture. The research range covered measurements of thermal properties of the created mixture such as: thermal conductivity coefficient $\lambda$, kinematic viscosity $v$, specific heat $c_{p}$, density $\rho$, and thermal expansion coefficient $\beta$. These properties determine the ability of the liquid to heat transfer: the heat transfer factor $\alpha$. The heat transfer factor $\alpha$ was determined on the basis of the equation presented by Dombek and Nadolny in [4]:

$$
\alpha=\sqrt[n+1]{c \cdot \lambda^{1-n} \cdot g^{n} \cdot \delta^{3 n-1} \cdot \beta^{n} \cdot \rho^{n} \cdot c_{p}^{n} \cdot v^{-n} \cdot q^{n}}
$$

where: $\alpha$ - heat transfer factor $\left[\mathrm{W} \cdot \mathrm{m}^{-2} \cdot \mathrm{K}^{-1}\right], c, n$ - constants dependent on the flow character, temperature and geometry, $\lambda-$ thermal conductivity $\left[\mathrm{W} \cdot \mathrm{m}^{-1} \cdot \mathrm{K}^{-1}\right], g$ - acceleration of gravity $\left[\mathrm{m} \cdot \mathrm{s}^{-2}\right], \delta$ - characteristic dimension $[\mathrm{m}], \beta-$ thermal expansion $\left[\mathrm{K}^{-1}\right], \rho-$ density $\left[\mathrm{g} \cdot \mathrm{l}^{-1}\right]$, $c_{p}$ - specific heat $\left[\mathrm{J} \cdot \mathrm{kg}^{-1} \cdot \mathrm{K}^{-1}\right], \mathrm{v}-$ kinematic viscosity $\left[\mathrm{mm}^{2} \cdot \mathrm{s}^{-1}\right], q-$ surface thermal load $\left[\mathrm{W} \cdot \mathrm{m}^{-2}\right]$.

For the measurements of the mentioned above properties the authors used synthetic esters named Midel 7131 manufactured by the company M\&I Materials and natural esters named Envirotemp FR3 manufactured by the company Cargil. The measurements of the properties were done according to standards $[1,9,24,25]$ using measurement systems which had been tested before on insulating liquids of thermal properties known from the literature. In order to do the investigations, the authors prepared mixtures of synthetic and natural esters of the following percentage concentrations of both the esters: $100 / 0,95 / 5,80 / 20,50 / 50,20 / 80,5 / 95$, and $0 / 100$. The measurements were taken for the temperatures of $25^{\circ} \mathrm{C}, 40^{\circ} \mathrm{C}, 60^{\circ} \mathrm{C}$, and $80^{\circ} \mathrm{C}$. The research results are presented in the subsequent section.

\section{Measurement results}

\subsection{Thermal conductivity $\lambda$ of a mixture of synthetic and natural esters}

Table 1 and Figure 1 present measurement results of thermal conductivity $\lambda$ of a mixture of synthetic and natural esters for different temperature values. With an increase of the natural ester content thermal conductivity of the mixture increases. Thermal conductivity $\lambda$ increased by $15.2 \%$ (for $25^{\circ} \mathrm{C}$ ), by $15.4 \%$ (for $40^{\circ} \mathrm{C}$ ), by $16.3 \%$ (for $60^{\circ} \mathrm{C}$ ), and by $15.9 \%$ (for $80^{\circ} \mathrm{C}$ ). This increase was independent of temperature. The reason of thermal conductivity increase is higher $\lambda$ of natural esters in comparison to synthetic esters [4]. In natural esters, because of stronger interaction of molecules, distances among them

Table 1. Measurement results of thermal conductivity $\lambda$ of a mixture of synthetic and natural esters

\begin{tabular}{||c|c|c|c|c|c|c|c||}
\hline \multicolumn{7}{|c|}{ Thermal conductivity $\lambda\left[\mathrm{W} \cdot \mathrm{m}^{-1} \cdot \mathrm{K}^{-1}\right]$} \\
\hline \multirow{3}{*}{ Temperature } & \multicolumn{7}{|c||}{ Proportion of synthetic esters (SE) and natural esters (NE) } \\
\cline { 2 - 9 } & $\begin{array}{c}100 \% \mathrm{SE} \\
0 \% \mathrm{NE}\end{array}$ & $\begin{array}{c}95 \% \mathrm{SE} \\
5 \%\end{array}$ & $\begin{array}{c}80 \% \mathrm{SE} \\
20 \% \mathrm{NE}\end{array}$ & $\begin{array}{c}50 \% \mathrm{SE} \\
50 \% \mathrm{NE}\end{array}$ & $\begin{array}{c}20 \% \mathrm{SE} \\
80 \% \mathrm{NE}\end{array}$ & $\begin{array}{c}5 \% \mathrm{SE} \\
95 \% \mathrm{NE}\end{array}$ & $\begin{array}{c}0 \% \mathrm{SE} \\
100 \% \mathrm{NE}\end{array}$ \\
\hline $25^{\circ} \mathrm{C}$ & 0.158 & 0.161 & 0.163 & 0.170 & 0.178 & 0.181 & 0.182 \\
\hline $40^{\circ} \mathrm{C}$ & 0.156 & 0.159 & 0.162 & 0.168 & 0.176 & 0.178 & 0.180 \\
\hline $60^{\circ} \mathrm{C}$ & 0.153 & 0.155 & 0.159 & 0.166 & 0.174 & 0.177 & 0.178 \\
\hline $80^{\circ} \mathrm{C}$ & 0.151 & 0.153 & 0.157 & 0.163 & 0.171 & 0.174 & 0.175 \\
\hline
\end{tabular}




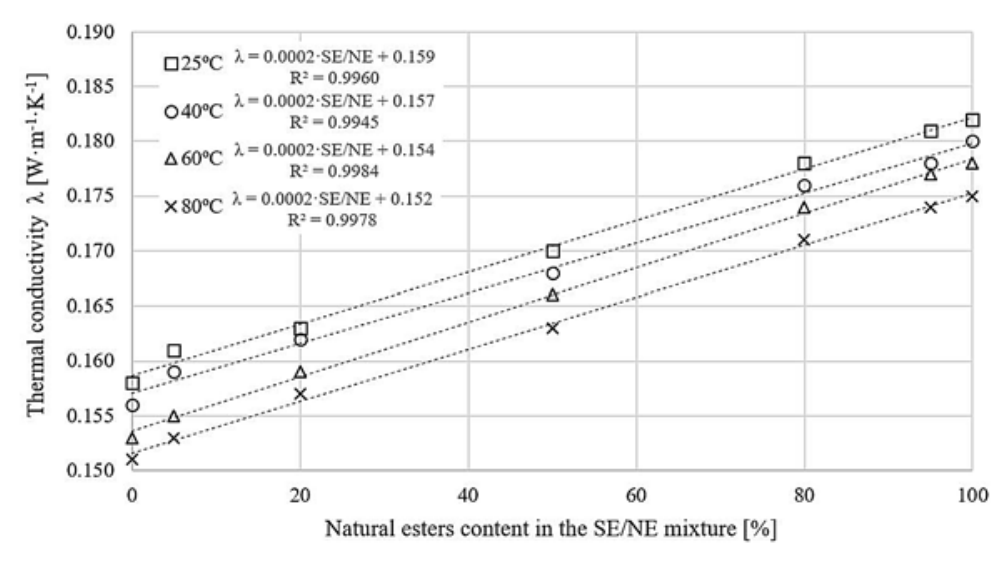

Fig. 1. Thermal conductivity $\lambda$ of a mixture of synthetic and natural esters

esters make forces of internal friction greater than for synthetic esters. Thus, mixture viscosity increases with increase of natural ester content, which can negatively affect the ability of the mixture to transfer heat in the transformer.

We can notice that when the temperature rises the viscosity of the mixture decreases. This drop should be linked with decreasing of attraction forces acting among liquid molecules as a result of a decrease of their kinetic energy. Kinetic energy increase results from temperature increase. In turn, when the temperature is higher the molecules move at higher velocities, which weakens intermolecular forces and as a result causes decrease of internal friction forces and viscosity decrease.

\subsection{Specific heat $c_{p}$ of a mixture of synthetic esters and natural esters}

Table 3 and Figure 3 present measurement results of specific heat $c_{p}$ of a mixture of synthetic esters and natural esters.

are shorter than for the case of synthetic ester, thus kinetic energy transfer is easier. This means that the higher content of natural esters the better will be thermal conductivity of the mixture, which can advantageously affect the ability of the mixture to transfer heat in the transformer.

With temperature increase we can also notice a decrease of thermal conductivity of the analysed mixtures. This drop is caused by distance increase among the molecules of the liquid which, as a result, makes kinetic energy transfer more difficult. Eventually, this causes lowering thermal conductivity of the analysed liquids.

Figure 1 presents measurement results with the trend line, equation of the approximation model, and determination factor. The results were approximated with the linear equation:

$$
\lambda=a \cdot S E / N E+b
$$

where: $a, b$ - constants which are material parameters of the $\mathrm{SE} / \mathrm{NE}$ mixture. Constant $a$ is equal to tangent of inclination angle of the straight line to the axis of ordinates. This constant determines changes of thermal conductivity $\lambda$ of an SE/NE mixture caused by the natural ester content. Constant $b$ is equal to thermal conductivity $\lambda$ for the natural ester content in the SE/ NE mixture equal to $0 \%$.

Results of the calculations of the remaining thermal properties (subsections 3.2-3.6) like for the case of thermal conductivity $\lambda$ were also approximated with the linear function.

\subsection{Kinematic viscosity $u$ of a mixture of synthetic and natural esters}

Table 2 and Figure 2 present measurement results of kinematic viscosity $v$ of a mixture of synthetic and natural esters. As it is shown, viscosity of the mixture increases by respectively $2.1 \%$ (for $25^{\circ} \mathrm{C}$ ), by $15.6 \%$ (for $40^{\circ} \mathrm{C}$ ), by $30.5 \%$ (for $60^{\circ} \mathrm{C}$ ), and by $41.8 \%$ (for $80^{\circ} \mathrm{C}$ ) with an increase of the natural ester content. With temperature increase, the viscosity increase resulting from increasing the natural ester content is clearer and clearer. This is caused by higher viscosity of natural esters, as presented by Dombek and Nadolny in [4]. Kinematic viscosity of liquids results directly from their chemical structure. Higher viscosity of natural esters is connected with stronger intermolecular interactions. These interactions in natural

\begin{tabular}{|c|c|c|c|c|c|c|c|}
\hline \multicolumn{8}{|c|}{ Specific heat $c_{p}\left[J \cdot \mathrm{kg}^{-1} \cdot \mathrm{K}^{-1}\right]$} \\
\hline \multirow[b]{2}{*}{ Temperature } & \multicolumn{7}{|c|}{ Proportion of synthetic esters (SE) and natural esters (NE) } \\
\hline & $\begin{array}{c}100 \% \mathrm{SE} \\
0 \% \mathrm{NE}\end{array}$ & $\begin{array}{l}95 \% \mathrm{SE} \\
5 \% \mathrm{NE}\end{array}$ & $\begin{array}{l}80 \% \mathrm{SE} \\
20 \% \mathrm{NE}\end{array}$ & $\begin{array}{l}50 \% \mathrm{SE} \\
50 \% \mathrm{NE}\end{array}$ & $\begin{array}{l}20 \% \mathrm{SE} \\
80 \% \mathrm{NE}\end{array}$ & $\begin{array}{c}5 \% \mathrm{SE} \\
95 \% \mathrm{NE}\end{array}$ & $\begin{array}{c}0 \% \mathrm{SE} \\
100 \% \mathrm{NE}\end{array}$ \\
\hline $25^{\circ} \mathrm{C}$ & 1905 & 1910 & 1923 & 1957 & 1977 & 2021 & 2028 \\
\hline $40^{\circ} \mathrm{C}$ & 1964 & 1969 & 1984 & 2014 & 2022 & 2069 & 2082 \\
\hline $60^{\circ} \mathrm{C}$ & 2052 & 2057 & 2078 & 2108 & 2117 & 2158 & 2166 \\
\hline $80^{\circ} \mathrm{C}$ & 2149 & 2154 & 2189 & 2218 & 2219 & 2246 & 2259 \\
\hline
\end{tabular}

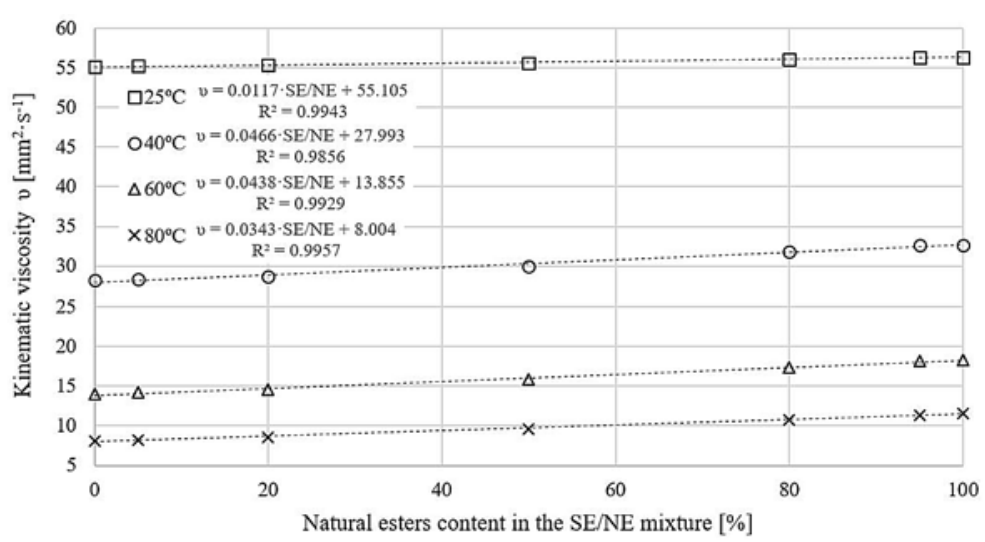

Fig. 2. Kinematic viscosity $v$ of a mixture of synthetic and natural esters 


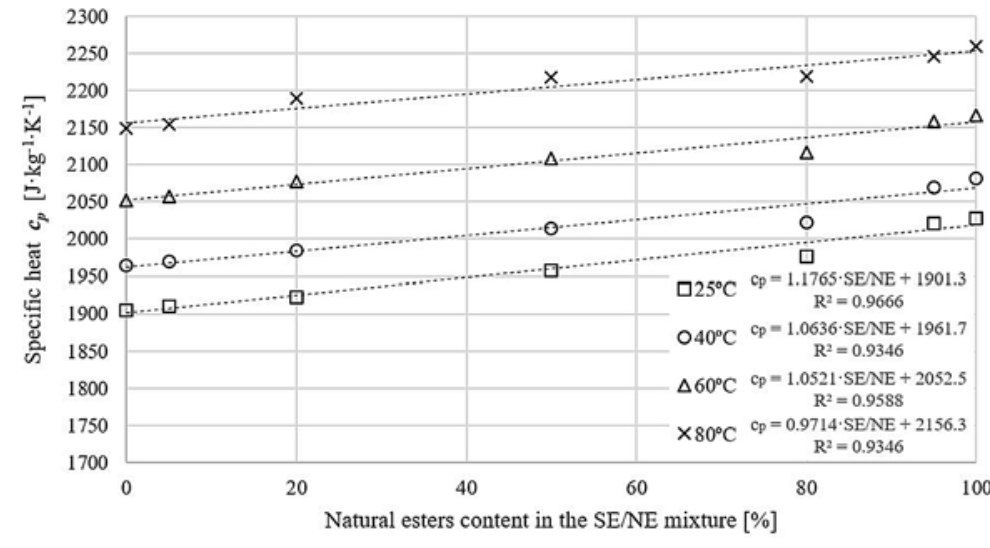

Fig. 3. Specific heat $\boldsymbol{c}_{\boldsymbol{p}}$ of a mixture of synthetic esters and natural esters

With an increase of the natural ester content the specific heat of the mixture increased slightly. Specific heat increased by $6.5 \%$ (for $25^{\circ} \mathrm{C}$ ), by $6.0 \%$ (for $40^{\circ} \mathrm{C}$ ), by $5.6 \%$ (for $60^{\circ} \mathrm{C}$ ), and by $5.1 \%$ (for $80^{\circ} \mathrm{C}$ ). With temperature rise, the increase of specific heat of the mixture caused by increasing the natural ester content, slightly decreased. The increase of $c_{p}$ of the mixture is caused by a higher value of specific heat of natural esters in comparison to the heat of synthetic esters. Specific heat is related to heat capacity, which determines the amount of energy that the molecules are able to absorb. Moreover, heat capacity is a function of molecule freedom degrees. It results from the above that the greater the particles the greater the number of freedom degrees they are characteristic of. Molecules of natural esters are larger than molecules of synthetic esters, therefore they can store more energy. The more energy a molecule can absorb the greater its heat capacity. In turn, the greater is heat capacity of a liquid, the greater its specific heat. As a

Table 4. Measurement results of density $\rho$ of a mixture of synthetic esters and natural esters

\begin{tabular}{|c|c|c|c|c|c|c|c|}
\hline \multicolumn{8}{|c|}{ Density $\rho\left[\mathrm{kg} \cdot \mathrm{m}^{-3}\right]$} \\
\hline \multirow{2}{*}{$\begin{array}{l}\text { Tempera- } \\
\text { ture }\end{array}$} & \multicolumn{7}{|c|}{ Proportion of synthetic esters (SE) and natural esters (NE) } \\
\hline & $\begin{array}{c}100 \% \mathrm{SE} \\
0 \% \mathrm{NE}\end{array}$ & $\begin{array}{c}95 \% \mathrm{SE} \\
5 \% \mathrm{NE}\end{array}$ & $\begin{array}{l}80 \% \text { SE } \\
20 \% \mathrm{NE}\end{array}$ & $\begin{array}{l}50 \% \mathrm{SE} \\
50 \% \mathrm{NE}\end{array}$ & $\begin{array}{l}20 \% \mathrm{SE} \\
80 \% \mathrm{NE}\end{array}$ & $\begin{array}{c}5 \% \mathrm{SE} \\
95 \% \mathrm{NE}\end{array}$ & $\begin{array}{c}0 \% \mathrm{SE} \\
100 \% \mathrm{NE}\end{array}$ \\
\hline $25^{\circ} \mathrm{C}$ & 964 & 962 & 955 & 941 & 926 & 919 & 917 \\
\hline $40^{\circ} \mathrm{C}$ & 953 & 951 & 944 & 931 & 917 & 910 & 908 \\
\hline $60^{\circ} \mathrm{C}$ & 940 & 938 & 930 & 916 & 902 & 894 & 892 \\
\hline $80^{\circ} \mathrm{C}$ & 926 & 924 & 917 & 903 & 889 & 882 & 880 \\
\hline
\end{tabular}

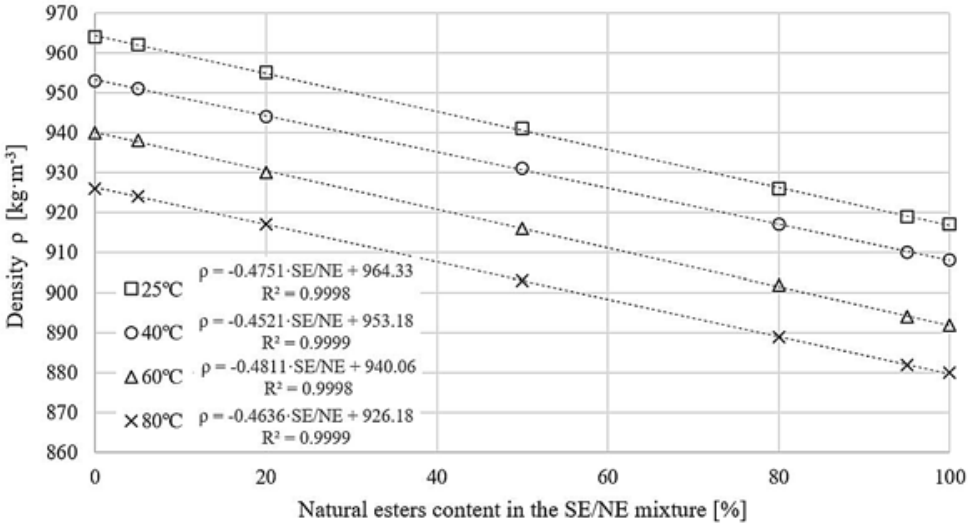

Fig. 4. Density $\rho$ of a mixture of synthetic esters and natural esters result, an increase of the natural ester content caused an increase of specific heat of the mixture, which can result in improvement of the mixture's ability to heat transfer in the transformer.

With temperature increase, specific heat increase is noticeable. This is connected with kinetic energy increase and potential oscillation of ester molecule atoms, thus a larger number of freedom degrees is possible. Kinetic energy is the greater, the greater the velocity of the moving molecules.

\subsection{Density $\rho$ of a mixture of synthetic esters and natu ral esters}

Table 4 and Figure 4 present measurement results of density $\rho$ of a mixture of synthetic and natural esters. With an increase of the natural ester content, the density of the mixture decreased a little. Density $\rho$ decreased by $4.9 \%$ (for $25^{\circ} \mathrm{C}$ ), by $4.7 \%$ (for $40^{\circ} \mathrm{C}$ ), by $5.1 \%$ (for $60^{\circ} \mathrm{C}$ ), and by $5.0 \%$ (for $80^{\circ} \mathrm{C}$ ). The density drop was practically independent of temperature. The drop of density $\rho$ results from the fact that density of natural esters is a little lower than density of synthetic esters. Minor density differences of the analysed liquids result from differences of intermolecular interactions. Thus we can conclude that with an increase of the natural ester content in the mixture, the density of such a mixture will decrease, affecting negatively its ability to transfer heat in the transformer.

Mixture density decreases with temperature increase because the molecules of the liquid move at greater velocity. Higher molecule velocity affects decreasing intermolecular forces, which eventually results in increasing distances among them. The increase of the distance among the molecules causes increase of the liquid volume, which means decrease of its density.

\subsection{Thermal expansion $\beta$ of a mixture of synthetic esters and natural esters}

Table 5 and Figure 5 present measurement results of thermal expansion $\beta$ of a mixture of synthetic and natural esters. As it is shown, an increase of natural ester content caused slight changes of thermal expansion of the mixture. Thermal expansion $\beta$ decreased by $2.6 \%$ (for $25^{\circ} \mathrm{C}$ ) and by $1.3 \%$ (for $40^{\circ} \mathrm{C}$ ), it did not change its value for $60^{\circ} \mathrm{C}$ and increased by $1.3 \%$ (for $80^{\circ} \mathrm{C}$ ). Minor changes of thermal expansion of the analysed liquids, like in the case of density, result from differences of intermolecular interactions. This means that with an increase of the natural ester content in the mixture, the thermal expansion of such a mixture changes slightly. This change should not significantly affect the ability of the mixture to heat transfer in the transformer.

With temperature increase, there is a noticeable increase of thermal expansion of the mixture. This increase results from the fact that liquid molecules vibrate at higher and higher frequency so their velocity increases. As a result of the velocity increase, the liquid molecules start moving apart, thus its spatial dimensions increase.

\subsection{Heat transfer factor $a$ of a mixture of synthetic esters and natural esters}

Table 6 and Figure 6 present calculation results of the heat transfer factor $\alpha$ of a mixture of synthetic and natural esters. The calculations were done on the basis of measurement results of the thermal properties described in subsections 3.1-3.5.

The increase of the natural ester content in the SE/NE mixture basically caused increase of factor $\alpha$. Its reason was an increase of thermal conductivity and specific heat resulting 
Table 5. Measurement results of thermal expansion $\beta$ of a mixture of synthetic esters and natural esters

\begin{tabular}{|c|c|c|c|c|c|c|c|}
\hline \multicolumn{8}{|c|}{ Thermal expansion $\beta\left[\mathrm{K}^{-1}\right]$} \\
\hline \multirow[b]{2}{*}{$\begin{array}{l}\text { Tempera- } \\
\text { ture }\end{array}$} & \multicolumn{7}{|c|}{ Proportion of synthetic esters (SE) and natural esters (NE) } \\
\hline & $\begin{array}{c}100 \% \mathrm{SE} \\
0 \% \mathrm{NE}\end{array}$ & $\begin{array}{c}95 \% \mathrm{SE} \\
5 \% \mathrm{NE}\end{array}$ & $\begin{array}{l}80 \% \text { SE } \\
20 \% \mathrm{NE}\end{array}$ & $\begin{array}{l}50 \% \text { SE } \\
50 \% \mathrm{NE}\end{array}$ & $\begin{array}{l}20 \% \mathrm{SE} \\
80 \% \mathrm{NE}\end{array}$ & $\begin{array}{c}5 \% \mathrm{SE} \\
95 \% \mathrm{NE}\end{array}$ & $\begin{array}{c}0 \% \mathrm{SE} \\
100 \% \\
\mathrm{NE}\end{array}$ \\
\hline $25^{\circ} \mathrm{C}$ & 0.00076 & 0.00076 & 0.00076 & 0.00075 & 0.00075 & 0.00074 & 0.00074 \\
\hline $40^{\circ} \mathrm{C}$ & 0.00077 & 0.00078 & 0.00077 & 0.00077 & 0.00077 & 0.00075 & 0.00076 \\
\hline $60^{\circ} \mathrm{C}$ & 0.00078 & 0.00078 & 0.00078 & 0.00078 & 0.00079 & 0.00078 & 0.00078 \\
\hline $80^{\circ} \mathrm{C}$ & 0.00079 & 0.00079 & 0.00080 & 0.00080 & 0.00081 & 0.00080 & 0.00080 \\
\hline
\end{tabular}

Table 6. Calculation results of the heat transfer factor $\alpha$ of a mixture of synthetic esters and natural esters

\begin{tabular}{||c|c|c|c|c|c|c|c|}
\hline \multicolumn{7}{|c|}{ Heat transfer factor $\alpha\left[\mathrm{W} \cdot \mathrm{m}^{-2} \cdot \mathrm{K}^{-1}\right]$} \\
\hline \multirow{2}{*}{$\begin{array}{c}\text { Tempera- } \\
\text { ture }\end{array}$} & $\begin{array}{c}100 \% \mathrm{SE} \\
0 \% \mathrm{NE}\end{array}$ & $\begin{array}{c}95 \% \mathrm{SE} \\
5 \% \mathrm{NE}\end{array}$ & $\begin{array}{c}80 \% \mathrm{SE} \\
20 \% \mathrm{NE}\end{array}$ & $\begin{array}{c}50 \% \mathrm{SE} \\
50 \% \mathrm{NE}\end{array}$ & $\begin{array}{c}20 \% \mathrm{SE} \\
80 \% \mathrm{NE}\end{array}$ & $\begin{array}{c}5 \% \mathrm{SE} \\
95 \% \mathrm{NE}\end{array}$ & $\begin{array}{c}0 \% \mathrm{SE} \\
100 \% \\
\mathrm{NE}\end{array}$ \\
\hline $25^{\circ} \mathrm{C}$ & 78.43 & 79.17 & 79.60 & 80.98 & 82.58 & 83.21 & 83.46 \\
\hline $40^{\circ} \mathrm{C}$ & 92.85 & 93.97 & 94.27 & 95.04 & 95.50 & 95.22 & 96.12 \\
\hline $60^{\circ} \mathrm{C}$ & 110.72 & 111.18 & 111.81 & 112.00 & 112.09 & 111.64 & 111.80 \\
\hline $80^{\circ} \mathrm{C}$ & 127.51 & 127.88 & 128.83 & 127.70 & 127.10 & 126.19 & 126.17 \\
\hline
\end{tabular}

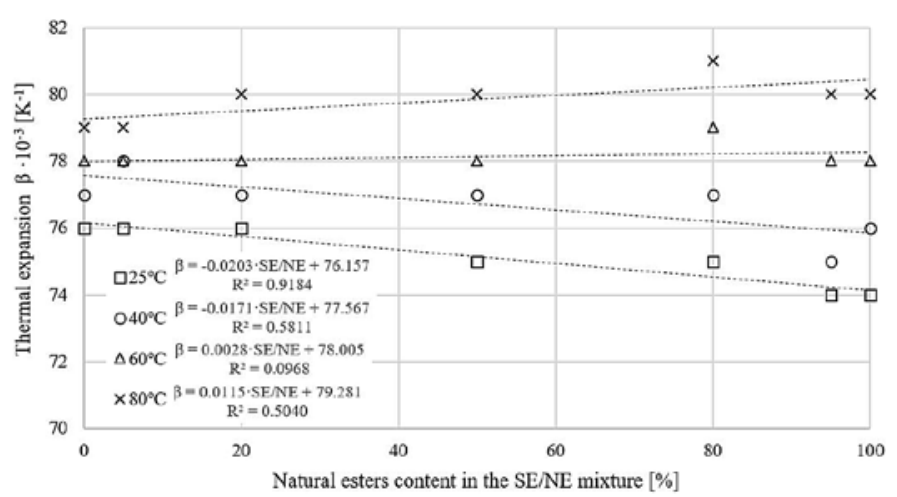

Fig. 5. Thermal expansion $\beta$ of a mixture of synthetic esters and natural esters

from adding natural esters, despite viscosity increase and decrease of density and thermal expansion. The authors also found that increases of factor $\alpha$ were getting smaller with temperature increase. The reason of this effect was a significant viscosity increase which resulted from adding natural esters for a higher and higher temperature values whereas changes of the remaining thermal properties remained at a constant level. The obtained results were predictable because the heat transfer factor of natural esters was greater than factor $\alpha$ of synthetic esters in the temperature range $25 \div 60^{\circ} \mathrm{C}$. At $80^{\circ} \mathrm{C}$ factor $\alpha$ of natural esters was a little lower than of synthetic esters.

The analysis of Figure 6 does not show a clear maximum of factor $\alpha$. This means that it is difficult to provide optimal proportions of both the esters. The only conclusions that come is the statement that in the case of the temperatures up to $60^{\circ} \mathrm{C}$, the application of natural esters is a more advantageous solution in terms of transformer cooling. At the temperature of $80^{\circ} \mathrm{C}$, factors $\alpha$ of both the esters are comparable.

\section{Conclusions}

An increase of the natural ester content in the SE/NE mixture caused changes of many thermal properties. Thermal conductivity increased by over 10 percent. Specific heat and density increased by a few percent. Viscosity, depending on temperature, increased by from a few to tens of percent. Thermal expansion practically did not change its value. The result of such changes was an increase of the heat transfer factor $\alpha$, depending on temperature, by from a few to over 10 percent.

The SE/NE mixture did not have an optimal composition, in terms of the value of the heat transfer factor $\alpha$. In fact, for $60^{\circ} \mathrm{C}$ and $80^{\circ} \mathrm{C}$ there are certain

\section{Reference}

1. ASTM D 1903-96. Standard test method for coefficient of thermal expansion of electrical insulating liquids of petroleum origin, and askarels.

2. Bertrand Y, Hoang L.C. Vegetable oils as substitute for mineral oils. Proceedings of the 7th International Conference on Properties and Applications of Dielectric Materials 2003: 491-494.

3. Cigre Brochure 436. Experiences in service with new insulating liquids. 2010.

4. Dombek G, Nadolny Z. Liquid kind, temperature, moisture, and ageing as an operating parameters conditioning reliability of transformer cooling system. Eksploatacja i Niezawodnosc - Maintenance and Reliability 2016; 18(3): 413-417, http://dx.doi.org/10.17531/ein.2016.3.13.

5. Dua R, Bhandari N, Kumar V. Multi-criteria optimization for obtaining efficiently blended transformer oil. IEEE Transactions on Dielectrics and Electrical Insulation 2008; 15(3): 879-887, http://dx.doi.org/10.1109/TDEI.2008.4543126. 
6. Fofana I, Wasserberg V, Borsi H, Gockenbach E. Challenge of mixed insulating liquids for use in high-voltage transformers, part 1: Investigation of mixed liquids. IEEE Electrical Insulation Magazine 2002; 18(3): 18-31, http://dx.doi.org/10.1109/MEI.2002.1014964.

7. Fofana I, Wasserberg V, Borsi H, Gockenbach E. Challenge of mixed insulating liquids for use in high-voltage transformers, part 2: Investigation of mixed liquid impregnated paper insulation. IEEE Electrical Insulation Magazine 2002; 18(4): 5-16, http://dx.doi.org/10.1109/ MEI.2002.1019901.

8. Fofana I, Wasserberg V, Borsi H, Gockenbach E. Retrofilling conditions of high-voltage transformers. IEEE Electrical Insulation Magazine 2001; 17(2): 17-30, http://dx.doi.org/10.1109/57.917528.

9. ISO 649-1:1981. Laboratory glassware - Density hydrometers for general purposes - Part 1: Specification.

10. Liao R, Hao J, Yang L, Grzybowski S. Study on aging characteristics of mineral oil/natural ester mixtures - paper insulation. IEEE International Conference on Dielectric Liquids (ICDL) 2011: 1-4.

11. Liao R, Hao J, Yang L, Liang S, Yin J. Improvement on the anti-aging properties of power transformers by using mixed insulating oil. International Conference on High Voltage Engineering and Application (ICHVE) 2010: 588-591, http://dx.doi.org/10.1109/ichve.2010.5640772.

12. Longva K. Natural ester distribution transformers; improved reliability and environmental safety. Nordic Insulation Symposium 2005: 293295.

13. Lopatkiewicz R, Nadolny Z. Temperature field on high voltage power transformer. Przeglad Elektrotechniczny 2008; 84(10): 50-52.

14. Lopatkiewicz R, Nadolny Z, Przybylek P. Influence of water content in paper on its thermal conductivity. Przeglad Elektrotechniczny 2010; 86(11B): 55-58.

15. Lopatkiewicz R, Nadolny Z, Przybylek P. The influence of water content on thermal conductivity of paper used as transformer windings insulation. 10th IEEE International Conference on the Properties and Applications of Dielectric Materials (ICPADM) 2012: 1-4, http:// dx.doi.org/10.1109/icpadm.2012.6318991.

16. Lopatkiewicz R, Nadolny Z, Przybylek P, Sikorski W. The influence of chosen parameters on thermal conductivity of windings insulation describing temperature distribution in transformer. Przeglad Elektrotechniczny 2012; 88(11B): 126-129.

17. McShane C.P. Relative properties of the new combustion resistant vegetable oil based dielectric coolants for distribution and power transformers. IEEE-IAS/PCA Cement Industry Technical Conference 2001: 31-40.

18. McShane C.P, Luksich J, Rapp K.J. Retrofilling aging transformers with natural ester based dielectric coolant for safety and life extension. IEEE-IAS/PCA Cement Industry Technical Conference 2003: 141-147, http://dx.doi.org/10.1109/citcon.2003.1204715.

19. Nadolny Z, Dombek G, Przybylek P. Thermal properties of a mixture of mineral oil and synthetic ester in terms of its application in the transformer. IEEE Conference of Electrical Insulation and Dielectric Phenomena (CEIDP) 2016: 857-860.

20. Nadolny Z, Dombek G, Przybylek P, Przadka D. Thermal properties of mineral oil admixed with $\mathrm{C}_{60}$ and TiO ${ }_{2}$ nanoparticles. IEEE Conference of Electrical Insulation and Dielectric Phenomena (CEIDP) 2016: 538-541.

21. Oommen T.V. Vegetable oils for liquid - filed transformers. IEEE Electrical Insulation Magazine 2002; 18, 6-11, http://dx.doi. org/10.1109/57.981322.

22. Perrier C, Beroual A, Bessede J.L. Experimental investigations on different insulating liquids and mixtures for power transformers. IEEE International Symposium on Electrical Insulation 2004: 237-240, http://dx.doi.org/10.1109/elinsl.2004.1380540.

23. Perrier C, Beroual A, Bessede J.L. Improvement of power transformers by using mixtures of mineral oil with synthetic esters. IEEE Transactions on Dielectrics and Electrical Insulation 2006; 13: 556-564, http://dx.doi.org/10.1109/TDEI.2006.1657968.

24. PN-EN ISO 3104. Przetwory naftowe - Ciecze przezroczyste i nieprzezroczyste - Oznaczanie lepkości kinematycznej i obliczanie lepkości dynamicznej.

25. PN-EN ISO 3675. Ropa naftowa i ciekłe przetwory naftowe - Laboratoryjne oznaczanie gęstości - Metoda $\mathrm{z}$ areometrem.

26. Rouse T.O. Mineral oil in transformer. IEEE Electrical Insulation Magazine 1998; 14: 6-16, http://dx.doi.org/10.1109/57.675572.

27. Suwarno, Darma I.S. Dielectric properties of mixtures between mineral oil and natural ester. International Symposium on Electrical Insulating Materials (ISEIM) 2008: 514-517, http://dx.doi.org/10.1109/iseim.2008.4664471.

28. Suwarno, Marbun J. Effect of thermal aging on the dielectric properties of mixture between mineral oil and natural ester. IEEE Region 10 Conference TENCON 2015: 1-5.

29. Toudja T, Chetibi F, Beldjilali A, Moulai H, Beroual A. Electrical and physicochemical properties of mineral and vegetable oils mixtures. IEEE International Comference on Liquid Dielectrics (ICDL) 2014: 1-4.

30. Trnka P, Mentlik V, Cerny J. Electroinsulating fluids - new insulating mixtures. Conference on Electrical Insulation and Dielectric Phenomena (CEIDP) 2011: 575-578, http://dx.doi.org/10.1109/ceidp.2011.6232722.

31. Trnka P, Mentlik V, Svoboda M. Ecologically acceptable insulating liquids for electrical appliances. IEEE 18th International Conference on Liquid Dielectric (ICDL) 2014: 1-4, http://dx.doi.org/10.1109/icdl.2014.6893121.

32. Wotzka D, Zmarzly D, Boczar T. Numerical simulation of acoustic wave propagating in a spherical object filled with insulating oil. Acta Physica Polonica A 2010; 118(6): 1272-1275, http://dx.doi.org/10.12693/APhysPolA.118.12

\section{Grzegorz DOMBEK \\ Zbigniew NADOLNY}

Institute of Electric Power Engineering

Poznan University of Technology

Piotrowo 3A, 60-965 Poznan, Poland

E-mail: grzegorz.dombek@put.poznan.pl,zbigniew.nadolny@put.poznan.pl 